\title{
How Did Lecturers and Students Adapt to online Learning During the Covid-19 Pandemic?
}

\author{
A case study in the Department of Biology, Universitas Negeri Surabaya
}

\author{
Ulfi Faizah* \\ Doctorate Program of Science Education \\ School of Post Graduates \\ Universitas Pendidikan Indonesia \\ Bandung, Indonesia \\ *ulfifaizah_19@upi.edu
}

\author{
Anna Permanasari \\ Department of Chemistry, Faculty of Mathematics and \\ Science Education \\ Universitas Pendidikan Indonesia \\ Bandung, Indonesia \\ anna.permanasari@upi.edu
}

\author{
Nuryani Y. Rustaman \\ Department of Biology, Faculty of Mathematics and Science Education, \\ Universitas Pendidikan Indonesia \\ Bandung, Indonesia \\ nuryanirustaman@upi.edu
}

\begin{abstract}
As most of the countries in the world, Indonesia Government now is applying Learning from Home (LFH) policy by implementing online learning. Lecturers and students must be able to adapt well. The adaptation can be an embodiment of the adult learning process (andragogy) and the application of Merdeka Belajar-Kampus Merdeka/Freedom Learning and Freedom Campus policy. This case study research aims to describe how lecturers and students in the Biology Department of Universitas Negeri Surabaya (Unesa) adapted to the implementation of online classes during the COVID-19 pandemic. The study was conducted during March-April 2020 involving 32 lecturers and 344 student respondents in the Biology Department, Unesa. The rapid survey was established on using Google form related to how they adapt to online learning as one of the learning facilities, the learning implementation, and their responses. The survey results were analyzed descriptively. The results show that lecturers and students, as learners andragogy, adapted learning with partner or individual learning. they made a joint agreement in choosing a variety of Learning Management Systems (LMS) and social media applications that will be suitable for them to conduct their online class. The type of LMS mostly used was google classroom (lecturer: $56.3 \%$, students: $89.9 \%$ ) while the application mostly used was WhatsApp (lecturer: 84.4\%; student: $94.5 \%$ ). The adaptation was done by establishing instructions on how to learn in an emergency period of COVID19 deployment. The learning was an embodiment of the Freedom Learning-Freedom Campus policy and it was focused on life skills education, considering the interests and conditions of students, some feedback was proposed by them, including the learning activity products. About $72 \%$ of lecturers and $56 \%$ of students responded the online learning positively.
\end{abstract}

Keywords-online learning, COVID-19 pandemic, case study, learning management systems

\section{INTRODUCTION}

Most governments around the world have temporarily closed educational institutions to prevent the spread of the Coronavirus disease-2019 pandemic (COVID-19). The closure affected nearly $70 \%$ of the world's student population. UNESCO supports countries that experience the direct impact of school closures, by facilitating the continuity of education for all through distance learning /online [1]. UNESCO supports the implementation of large-scale online learning programs and recommends open education applications and platforms that schools and teachers can use to reach students remotely. This organization shares best practices for utilizing inexpensive cellular technology for teaching and learning purposes to reduce obstacles in the education field [2]. Various countries in the world have implemented online learning for the sustainability of educational programs for example in the Philippines, Fiji, China, and other countries [3-9].

In Indonesia, this outbreak has also pushed for work from home policies. The COVID-19 pandemic emergency response effort in Indonesia encouraged universities and the academic community to use online learning methods as a substitute for face-to-face lectures which were temporarily eliminated to prevent the spread of the COVID-19 virus from spreading. This was in line with the call of the Minister of Education and Culture in Circular Letter Number 36962 / MPK.A /HK /2020 dated March 17, 2020, concerning Online Learning and Working from Home in the framework of Preventing the Spread of COVID-19 and Circular Letter Number 4 of 2020 concerning Implementation Education Policy in the Emergency of COVID Spread 19 Online Learning and Working from Home in the Context of Preventing the Spread of COVID-19 to 
serve as a guideline in Higher Education. The letter explained several provisions, one of which was about the instruction of the learning process at home. In implementing the learning process, education providers must pay attention to four main provisions namely the implementation of online learning, focus on life skills education, pay attention to students' interests and conditions, provide feedback from the evidence of learning activities [10,11]. Universitas Negeri Surabaya (Unesa) followed up on the circular by issuing a circular letter from Unesa Number: B / 15254 /UN38/TU.00.02/2020 concerning Preventive Measures for COVID-19 spread at Unesa, one of the points being to determine lectures carried out online.

Faced with the changes that occur in the learning process on a future pandemic COVID 19, lectures and students in the Department of Biology Unesa certainly have had to adapt to keep running the course. The adaptation can be an embodiment of the adult learning process (andragogy) and the application of the Freedom Learning-Freedom Campus policy. Andragogy is an adult learning concept with a process that fosters a desire to ask questions and learn on an ongoing basis throughout life. For adults, learning relates to how to direct yourself to ask questions and seek answers to the problems they face [12]. In the perspective of andragogy, an adult learning environment is an environment that is challenging enough to be further developed into reflective learning that requires critical thinking skills to combine life experiences with current activities, using relevant and timely technology to achieve the goals and tasks given, and the technology allows to be studied independently [13]. Application of the Freedom Learning-Freedom Campus policy is to implement the notion of an independent study that is the freedom to learn to allow students to learn freely and free to learn to calm, relaxed and happy without the stress and pressure. This is done by paying attention to their natural talents, without forcing them to learn or master a field of knowledge outside their hobbies and abilities so that each has a portfolio that suits their desires [14]. Related to the Freedom Campus, the program is an effort of freedom in the higher education system to support more students and lecturers in achieving quality learning meaningfully facing the challenges of the times [15].

This case study research aims to describe how the lecturers and students in the Biology Department were adapting to online learning during the COVID pandemic 19.

\section{METHODS}

This case study was conducted in March-April 2020. Sources of information were obtained from 32 lecturers and 344 students majoring in Biology Unesa consisting of four batches, namely classes 2019, 2018, and 2017, which carried out online learning at home during the COVID-19 pandemic conditions. The type of instrument used in providing questionnaires related to the implementation of online learning. Data collection techniques in this study were by rapid survey distributing questionnaires through Google form to lecturers and students majoring in biology. The data analysis strategy was done descriptively qualitatively, which was to give an overview of how lecturers and students in the Department of Biology Unesa adapted to online learning during the COVID19 pandemic.

\section{RESULTS AND DISCUSSION}

The results of this study indicated that in implementing online learning the respondents have adapted using various alternative online learning media, namely Learning Management Systems (LMS) and social media applications. The most widely used LMS media was Google Classroom (lecturer: $56.3 \%$, student: $89.9 \%$ ) while the most widely used online application was WhatsApp (lecturer: 84.4\%; student: $94.5 \%$ ). Other media that are used are Facebook, the zoom application, the TeamLink application, the Vilearning Unesa application, Google meets, Timeviewer, Google Drive, Edmodo, Schoology, hangout meet. These learning media are following the results of research conducted by several researchers in other places [16-18].

Initially, lecturers and students in the Biology Department were accustomed to using offline learning, but now they had to adapt to carry out online learning. The variety of existing online learning media causes them to have to learn in advance to utilize online learning media so that lectures can still be carried out well. Some study independently, some study together with partners (fellow lecturers/fellow students). Lecturers and students also carried out joint agreements in determining the online learning media that they use in lectures. The process of learning to operate online media is an embodiment of the adult learning process (andragogy). There are four principles of adult learning, namely: 1. Adults need to be involved in designing and making learning goals. They must understand the extent of achieving results. 2. Experience is the principle of learning activities. It is the responsibility of students to accept the experience as meaningful.

3. Adults are more interested in learning materials that are directly related to their work and life. 4. Learning is more focused on problems (problem-centered) and requires encouragement and motivation [19].

The principles of adult learning in the digital literacy era are: 1 . Adult learning is very different from children's learning. The rules of learning that are often used in adult learning are group conversations, problem-solving, and exchanging experiences based on information technology. 2. Adults learn better if they are actively involved in the process of designing, assessing, and implementing the learning process that they follow. 3. Adults learn more memorable if the topic was worth and be able to help the problems faced in their daily life and workday. 4. Adults learn best when they have the motivation to change, are self-discovered, or have specific skills and strategies based online. 5. One of the obstacles in adult learning is that adults in general already have the knowledge and attitude so it is difficult to accept change [12].

Non-traditional/on-line teaching models combine characteristics related to andragogy, including discussing communication and interaction between lecturers and students, 
encouraging the provision of cognitive support to improve critical thinking and problem-solving skills, while teaching students how to search, retrieve, and use information, and add efficient learning time by focusing more on learning discussion content to fill learning gaps [20] Andragogy learning encourages learners to be able to increase their learning levels higher [21].

For the implementation of online learning in lecturing activities, the adaptation lecturers and students carried out were following instructions from the Ministry of Education and the Chancellor of Unesa related to the implementation of online learning during the COVID-19 pandemic. The results of research related to teaching materials used indicate that the lecture material online students studied was provided in Figure 1. The most was provided by Inserted into learning applications for example on Google Classroom, Vilearning Unesa. The online lecture schedule was carried out following schedule has been previously scheduled (lecturers: $84.8 \%$, students: $71.8 \%$ ). The time for an online lecture was determined/limited, there was a deadline collecting time (lecturers: 93.8\%, students: $91.6 \%)$.

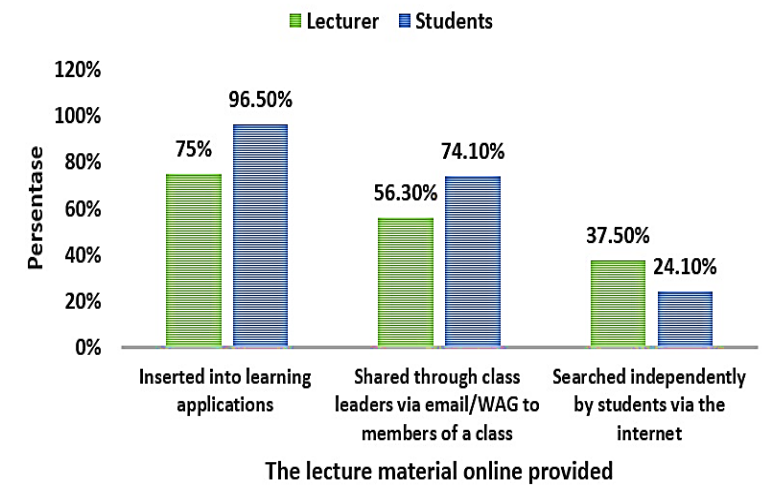

Fig. 1. Teaching materials used in the lecture material online.

Related to practicum courses, the results of the research showed in Figure 2. There were A lot of practicum activities replaced with other assignments. These results indicate that lectures with practical activities are quite difficult to do online so that this activity according to many respondents is devoted to other activities/ tasks.

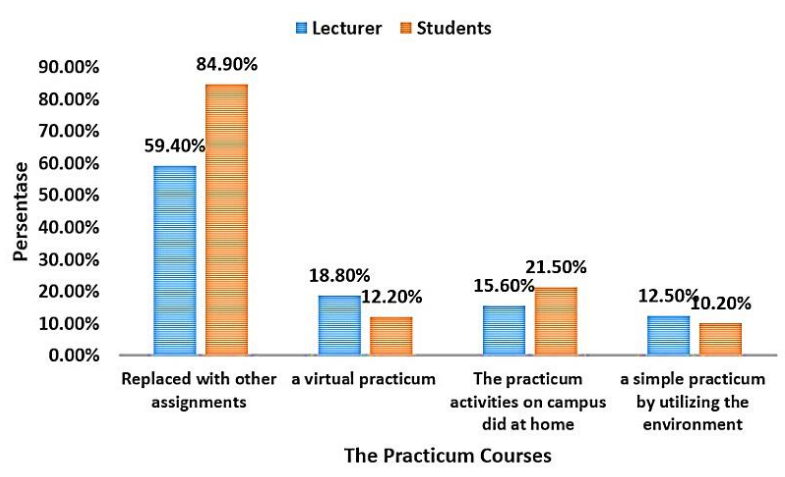

Fig. 2. The profile of practical results in online courses.
Online lecture assessment is done using like at Figure 3 Important assessment factors between lecturers and students have different perceptions, students assume the assessment of activity is more valued than the suitability of the answers. The task was given, this needs to be conveyed to students will they do their assignments well and keep their activities active during online lectures.

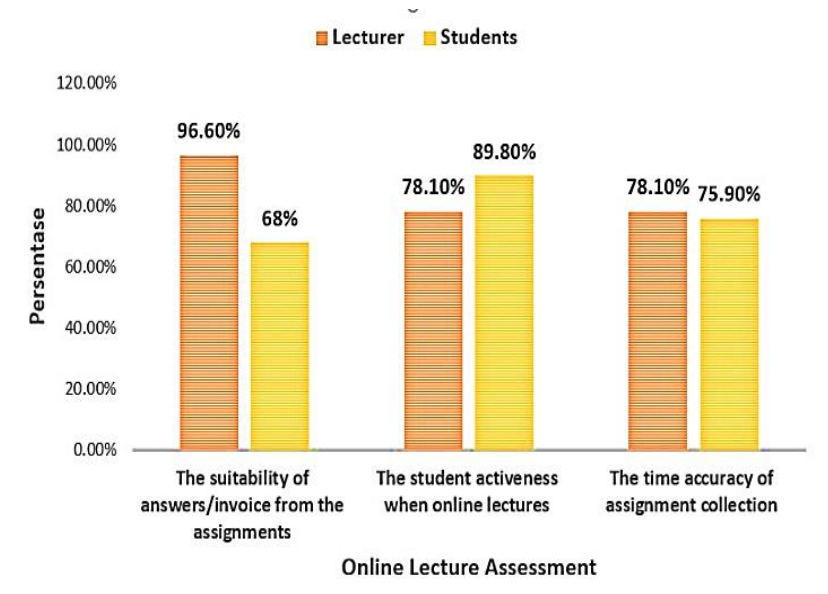

Fig. 3. The assessment at online courses.

Feedback from online lecture implementation and assignments given by doing it directly through online learning media used so that students can follow up (lecturers: $71.9 \%$, students: $70.6 \%$ ). Most of the lecturers have implemented feedback and are supported with the same student responses. Hopefully, all lecturers can give feedback on the assignments of their students.

Life skills regarding the COVID-19 pandemic in online lectures include in Figure 4. The message about Clean and Healthy Behavior inserted in the online lecture were popular to take in courses. Important life skills are given in lectures during the COVID-19 pandemic conditions like this so that lectures become meaningful. This research shows that life skills have been given in several ways.

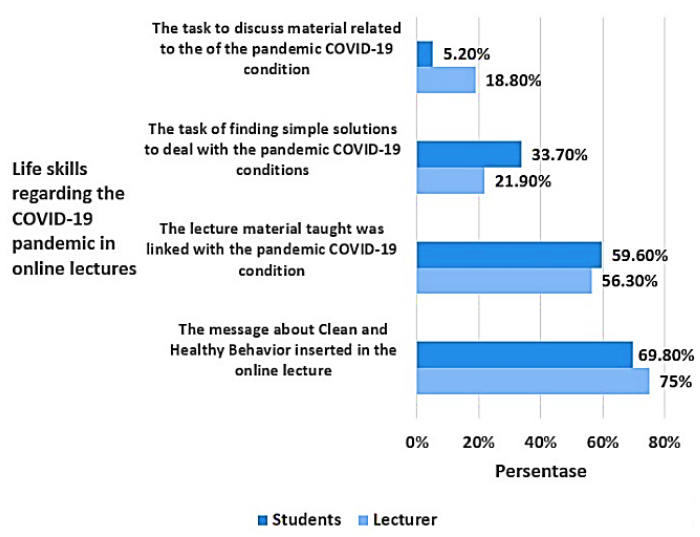

Fig. 4. The COVID-19 pandemic Life skills in online lectures. 
Implementation of online learning is conducted by considering the condition of the students. This research shows the results of technical and non-technical difficulties experienced by students. The common online technical difficulties encountered by students were in Figure 5. The internet quota limitations were big problem. The condition of students related to quota limitations was known to be a technical problem in online learning, following this up, Unesa had issued a circular about internet quota assistance for students who need to help their lectures run smoothly.

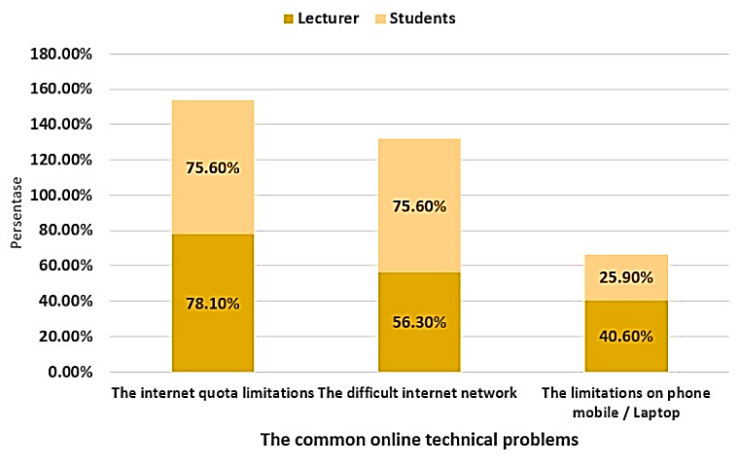

Fig. 5. The common online technical difficulties encountered by students.

While the non-technical problems experienced by students indicated by this research at Figure 6. Lecture thought the limited of a practicum tools was a main problem, but students opinion said the limited ability to understand the material being taught online was big problem for them.

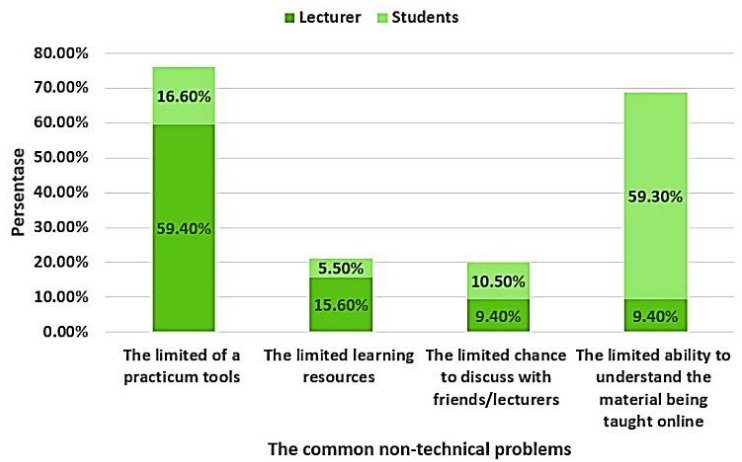

Fig. 6. The non-technical problems experienced by students.

These results indicated that it turns out that the biggest nontechnical problems for students when learning online was many of the students did not understand the material provided in online learning, it was not a matter of limited practical tools as stated by the lecturer. Adaptation to understand the material of the implementation of online learning does require time when this research is conducted online learning has taken place three times the meeting of nine scheduled. The expectation, Andragogy students will adapt along with time, the more often students carry out online learning and they will become accustomed to and it will be easier to understand the material presented.

In general, it can be seen that the teachers and students adapted to implement online learning in addition to learning andragogy also adjust with government directives related to the implementation of learning in the COVID-19 pandemic. Education organizer in the Department of Biology Unesa, Lecturer and students have to adapted to take into account four main provisions: 1. learning from home through online or distance learning is carried out to provide a meaningful learning experience for students, without being burdened with the demands of completing all curriculum achievements for grade promotion or graduation; 2. learning from home can be focused on life skills education including the COVID-19 pandemic; 3 . The activities and tasks of learning from home can variation between students, according to their interests and conditions of each, including considering the disparity of access or learning facilities at home, 4. evidence of learning activities or products of home baited both qualitative and useful from lecturers, without being required to give scores or quantitative scores [10].

Related to the adaptation to the implementation of the Freedom Learning-Freedom Campus program, the results of this study showed that in the situation of the COVID-19 pandemic, it was necessary to implement an independent learning program. Currently, lecturers and students needed selfquarantine and social distance. By implementing online learning, lecturers and students could implement independence in learning and free online browsing. Learning could be done anywhere, from home, room, garden, dorm room, or dormitory as long as you want to learn. Online facilities that support ranging from social media, YouTube, Facebook, WhatsApp, Twitter, Google Classroom, Line, Zoom, Kahoot, Schoology, etc. enable for everyone to do independent learning [14].

Besides, Freedom learning Education is a response to the needs of the education system in the Industrial Revolution 4.0 era. In the era of the Industrial Revolution 4.0, the main needs to be achieved in the education system or more specifically in the learning method anew literacy. The new literacy is 1) data literacy, 2) technological literacy, 3) human literacy. The Freedom Learning System continues to prioritize the character of education. The application of new literacy in lecture activities wares to conduct online learning as was currently done in the COVID-19 pandemic [22]. Freedom Campus as part of learning independence is a more comprehensive interpretation of freedom that will realize real efforts by all Indonesian people to achieve prosperity, intellectual life, and maintain world order [15].

The response of this study was $72 \%$ of lecturers and $56 \%$ of students responded positively to the implementation of online learning because they got benefit from increased digital literacy/ICT skills. This positive response showed that lecturers and students can adapt well to the implementation of online learning in the COVID-19 pandemic condition. 


\section{CONCLUSIONS}

The lecturers and students of the Department of Biology, Universitas Negeri Surabaya (Unesa) in conducting online classes during the COVID 19 pandemic adapted to learning with andragogy learning and carried out learning according to the Indonesian government's orders about implementing learning in an emergency of COVID-19 deployment following the policy of Freedom Learning and Freedom Campus.

\section{ACKNOWLEDGMENT}

Acknowledgments are given to Lembaga Pengelola Dana Pendidikan (LPDP) Kementerian Keuangan Republik Indonesia for scholarship, research and publication costs.

\section{REFERENCES}

[1] Unesco, "Covid-19 Educational Disruption And Response," Retrieved May 29, 2020, from Https://En.Unesco.Org/Themes/EducationEmergencies/Coronavirus-School-Closures

[2] Unesco, "290 Million Students Out Of School Due To Covid-19: Unesco Releases First Global Numbers And Mobilizes Response,' Retrieved May 29, 2020, from Https://En.Unesco.Org/News/290Million-Students-Out-School-Due-Covid-19-Unesco-Releases-FirstGlobal-Numbers-And-Mobilizes

[3] C.M. Toquero, "Challenges and Opportunities for Higher Education Amid The Covid-19 Pandemic: The Philippine Context," Pedagogical Research 2020, vol. 5, no. 4, 2020

[4] W. Ali, "Online and Remote Learning in Higher Education Institutes: A Necessity in Light of Covid-19 Pandemic," Higher Education Studies, vol. 10, no. 3, 2020

[5] W. Zhang, Y. Wang, L. Yang, and C. Wang, Suspending classes without stopping learning: China's education emergency management policy in the COVID-19 outbreak, 2020.

[6] L. Zhou, S. Wu, M. Zhou and F. Li, School's Out, But Class' On', The Largest Online Education in the World Today: Taking China's Practical Exploration During The COVID-19 Epidemic Prevention and Control As an Example. But Class' On', The Largest Online Education in the World Today: Taking China's Practical Exploration During The COVID-19 Epidemic Prevention and Control As an Example (March 15, 2020)

[7] J. Demuyakor, "Corona Virus (Covid-19) and Online Learning in Higher Institutions of Education: A survey of The Perceptions of Ghanaian International Students in China," Online Journal of Communication and Media Technologies, vol. 10, no. 3, 2020.

[8] W. Bao, Covid-19 and Online Teaching in Higher Education: A Case Study of Peking University. Hum Behav \& Emerg Tech. 2020; 2:113 115. Https://Doi.Org/ 10.1002/ Hbe2.191

[9] J. Crawford, K. Butler-Henderson, J. Rudolph, B. Malkawi, M. Glowatz, R. Burton and S. Lam, "COVID-19: 20 countries' higher education intra- period digital pedagogy responses," Journal of Applied Learning \& Teaching, vol. 3, no. 1, pp. 1-20, 2020

[10] Kemendikbud. 2020. Mendikbud Terbitkan SE Tentang Pelaksanaan Pendidikan dalam Masa Darurat Covid-19. Retrieved May 29, 2020 from Https://Www.Kemdikbud.Go.Id/Main/Blog/2020/03/MendikbudTerbitkan-Se-Tentang-Pelaksanaan-Pendidikan-Dalam-Masa-DaruratCovid19

[11] M.B.N. Wajdi, I. Kuswandi, U. Al Faruq, Z. Zulhijra, K. Khairudin, and K. Khoiriyah, "Education Policy Overcome Coronavirus, A Study of Indonesians," EDUTEC: Journal of Education And Technology, vol. 3, no. 2, pp. 96-106, 2020

[12] W. Wahono, N. Imsiyah, and A. Setiawan, "Andragogi: Paradigma Pembelajaran Orang Dewasa Pada Era Literasi Digital," Proceeding Umsurabaya, 2020

[13] R. Halpern and Tucker C, "Leveraging Adult Learning Theory with Online tutorials". Reference Services Review, vol. 43, no. 1, pp. 112 $124,2015$.

[14] A. Abidah, H.N. Hidaayatullaah, R.M. Simamora, D. Fehabutar, and L. Mutakinati, "The impact of COVID-19 to Indonesian Education and its Relation to the philosophy of "Merdeka Belajar"," Studies in Philosophy of Science and Education, vol. 1, no. 1, pp. 38-49, 2020.

[15] B.K. Prahani, U.A. Deta, M. Yasir, S. Astutik, P. Pandiangan, S Mahtari and H. Mubarok, "The Concept of" Kampus Merdeka" in Accordance with Freire's Critical Pedagogy," Studies in Philosophy of Science and Education, vol. 1, no. 1, pp. 21-37, 2020

[16] G. Gunawan, N.M.Y. Suranti, and F. Fathoroni, "Variations of model and learning platforms for prospective teachers during the COVID-19 pandemic period," Indonesian Journal of Teacher Education, vol. 1, no. 2, pp. 61-70, 2020.

[17] R. Pakpahan and Y. Fitriani, "Analisa pemanfaatan teknologi informas dalam pembelajaran jarak jauh di tengah pandemi virus corona covid19," Journal of Information System, Applied, Management, Accounting and Research, vol. 4, no. 2, pp. 30-36, 2020.

[18] G. Basilaia and D. Kvavadze, "Transition to Online Education in Schools During A Sars-Cov-2 Coronavirus (Covid-19) Pandemic in Georgia," Pedagogical Research, vol. 5, no. 4, 2020.

[19] M.S. Knowles, The Modern Practice of Adult Education: From Pedagogy to Andragogy. (2nd Ed.) Chicago: Follett, 1980.

[20] R.F. Schmid, R.M. Bernard, E. Borokhovski, R. Tamim, P.C. Abrami, C.A. Wade and G. Lowerison, "Technology's Effect on Achievement in Higher Education: A Stage I Meta-Analysis of Classroom Applications". Journal of Computing in Higher Education, vol. 21, no. 2, pp. 95-109, 2009

[21] P. Allen, P. Withey, D. Lawton, and C.T. Aquino, "Andragogical Teaching Methods to Enhance Non-Traditional Student Classroom Engagement," Journal of Educational Technology, vol. 13, no. 2, pp. 47 59, 2016.

[22] M. Yamin and Syahrir, "Pembangunan Pendidikan Merdeka Belajar (Telaah Metode Pembelajaran)," Jurnal Ilmiah Mandala Education, vol 6 , no. $1,2020$. 